University of Nebraska - Lincoln

DigitalCommons@University of Nebraska - Lincoln

Agronomy \& Horticulture -- Faculty Publications

Agronomy and Horticulture Department

$3-1-2008$

\title{
Soybean Sowing Date: The Vegetative, Reproductive, and Agronomic Impacts
}

\author{
A. M. Bastidas \\ University of Nebraska-Lincoln \\ T. D. Setiyono \\ University of Nebraska-Lincoln, tsetiyono2@unl.edu \\ Achim Dobermann \\ University of Nebraska-Lincoln \\ Kenneth G. Cassman \\ University of Nebraska-Lincoln, kcassman1@unl.edu \\ Roger Wesley Elmore \\ University of Nebraska-Lincoln, roger.elmore@unl.edu
}

See next page for additional authors

Follow this and additional works at: https://digitalcommons.unl.edu/agronomyfacpub

Part of the Plant Sciences Commons

\begin{abstract}
Bastidas, A. M.; Setiyono, T. D.; Dobermann, Achim; Cassman, Kenneth G.; Elmore, Roger Wesley; Graef, George L.; and Specht, James E., "Soybean Sowing Date: The Vegetative, Reproductive, and Agronomic Impacts" (2008). Agronomy \& Horticulture -- Faculty Publications. 99.

https://digitalcommons.unl.edu/agronomyfacpub/99
\end{abstract}

This Article is brought to you for free and open access by the Agronomy and Horticulture Department at DigitalCommons@University of Nebraska - Lincoln. It has been accepted for inclusion in Agronomy \& Horticulture -Faculty Publications by an authorized administrator of DigitalCommons@University of Nebraska - Lincoln. 


\section{Authors}

A. M. Bastidas, T. D. Setiyono, Achim Dobermann, Kenneth G. Cassman, Roger Wesley Elmore, George L. Graef, and James E. Specht 


\title{
Soybean Sowing Date: The Vegetative, Reproductive, and Agronomic Impacts
}

\author{
A. M. Bastidas, T. D. Setiyono, A. Dobermann, K. G. Cassman, \\ R. W. Elmore, G. L. Graef, and J. E. Specht`
}

\section{ABSTRACT}

The sensitivity of soybean [Glycine max (L.) Merr.] main stem node accrual to ambient temperature has been documented in greenhousegrown plants but not with field-grown plants in the north-central United States. Biweekly V-node and R-stage, stem node number, internode length, and other traits were quantified in an irrigated split-plot, four-replicate, randomized complete block experiment conducted in Lincoln, NE, in 2003-2004. Main plots were early-, mid-, lateMay, and mid-June sowing dates. Subplots were 14 cultivars of maturity groups 3.0 to 3.9. Node appearance was surprisingly linear from V1 to R5, despite the large increase in daily temperature from early May $\left(10-15^{\circ} \mathrm{C}\right)$ to July $\left(20-25^{\circ} \mathrm{C}\right)$. The 2003 and 2004 May planting date regressions exhibited near-identical slopes of 0.27 node $\mathrm{d}^{-1}$ (i.e., one node every 3.7 d). Cold-induced delays in germination and emergence did delay the V1 date (relative to planting date), so the primary effect of temperature was the V1 start date of linearity in node appearance. With one exception, earlier sowings led to more nodes (earlier V1 start dates) but also resulted in shorter internodes at nodes 3 to 9 (cooler coincident temperatures), thereby generating a curved response of plant height to delayed plantings. Delaying planting after 1 May led to significant linear seed yield declines of $17 \mathrm{~kg} \mathrm{ha}^{-1} \mathrm{~d}^{-1}$ in 2003 and $43 \mathrm{~kg} \mathrm{ha}^{-1}$ $\mathrm{d}^{-1}$ in 2004, denoting the importance of early planting for capturing the yield potential available in soybean production, when moisture supply is not limiting.
A.M. Bastidas, T.D. Setiyono, A. Dobermann, K.G. Cassman, G.L. Graef, and J.E. Specht, Dep. of Agronomy and Horticulture, Univ. of Nebraska, Lincoln, NE 68583-0915; R.W. Elmore, Dep. of Agronomy, Iowa State Univ., Ames, IA 50011. Contribution of the Dep. of Agronomy and Horticulture, Univ. of Nebraska, Lincoln, NE 68583. Published as Paper no. 15201, Journal Series Nebraska Agric. Exp. Stn. Project No. 12-194. Funding for this research was received from the Nebraska Agricultural Research Division, Nebraska Soybean Development, Utilization, and Marketing Board, United Soybean Board, and Fluid Fertilizer Foundation. Received 4 May 2006. *Corresponding author(jspecht1@unl.edu).

\begin{abstract}
Abbreviations: CI, confidence interval; DAP, days after planting; Ddf, denominator degrees of freedom; DOY, day of year; ET, evapotranspiration; MG, maturity group; Ndf, numerator degrees of freedom; R, reproductive; $\mathrm{V}$, vegetative.
\end{abstract}

$I^{N}$ N The U.S. Corn Belt, soybean [Glycine max (L.) Merr.] planting typically peaks during mid- to late May (Pendleton and Hartwig, 1973; Hoeft et al., 2000). Effects of planting date on soybean yield and other traits at various north-central U.S. locations have been documented in Ohio by Beuerlein (1988), in Indiana by Wilcox and Frankenberger (1987), in Illinois by Beaver and Johnson (1981) and by Anderson and Vasilas (1985), in Iowa by Schnebly and Fehr (1993), in Wisconsin by Oplinger and Philbrook (1992) and by Pedersen and Lauer (2003, 2004a, 2004b), in North Dakota by Helms et al. (1990), and in Nebraska by Elmore (1990). Statespecific extension publications documenting planting date studies conducted for a decade or more at a given site are also available on the Web (e.g., Naeve et al., 2004; Pecinovsky and Benson, 2004; Whigham et al., 2000). The predominant conclusion reached in most of those studies is that maximum yield is generally achieved

Published in Crop Sci. 48:727-740 (2008).

doi: $10.2135 /$ cropsci2006.05.0292

(C) Crop Science Society of America

677 S. Segoe Rd., Madison, WI 53711 USA

All rights reserved. No part of this periodical may be reproduced or transmitted in any form or by any means, electronic or mechanical, including photocopying, recording, or any information storage and retrieval system, without permission in writing from the publisher. Permission for printing and for reprinting the material contained herein has been obtained by the publisher. 
with mid-May plantings, with yield declining significantly if sowing is delayed into late May or early June-even more with delays beyond mid-June. Despite this wealth of information, reports differ as to whether it is better to plant in early May (or late April) or in mid-May, primarily because yields in the former have not been consistent.

While variation in soybean planting date is expected to impact the pattern of soybean growth and development, very few reports have examined this issue in detail. A method for evaluating soybean vegetative $(\mathrm{V})$ and reproductive (R) development was first documented by Fehr et al. (1971). The key V-node and R-stage parameters were graphically illustrated in a later bulletin (Fehr and Caviness, 1977) and with pictures by Pedersen (2004). This staging system is now the standard method used to document phenological development in soybean.

Pedersen and Lauer (2003, 2004a, 2004b) conducted one of the few detailed studies on the effects of early (3-6 May) vs. late (23-27 May) planting dates by examining soybean growth, development, and yield in a 4-yr experiment located in Wisconsin. They observed that the start of each reproductive stage-from R1 (begin flower) to R5 (begin seed) - was delayed by the 3-wk delay in planting date, except for stage R6 (full seed), which occurred coincidently in both planting dates at $105 \mathrm{~d}$ after emergence. Seed number and pod number were greater, but seed per pod was lower, in the early May planting date. However, these yield component differences were small, offering little explanation for the difference in 4-yr seed yield means between $4.23 \mathrm{Mg} \mathrm{ha}^{-1}$ recorded in the early May plantings and $3.85 \mathrm{Mg} \mathrm{ha}^{-1}$ in the late May plantings.

Pedersen and Lauer (2004a) also used data they collected at 20-d intervals to examine seasonal patterns in plant height and node appearance. At $64 \mathrm{~d}$ after emergence, plants in the late May planting were $35 \mathrm{~cm}$ shorter than plants in the early May planting, but at R6, plants in both planting dates were nearly equal in height. The authors concluded that planting date did not have an effect on plant height at harvest. Many soybean producers in Nebraska and elsewhere have drawn a similar conclusion based on their own experience with planting dates, but unfortunately this has led some to believe that plants in late plantings can "catch up" with the plants in early May plantings in traits other than just plant height. Pedersen and Lauer (2004a) did note that plants in the early May planting averaged 16.3 main stem nodes at maturity, compared to an average of 15.5 mature nodes in the late May planting. Our examination of their data indicated that stem node 8, which was attained about $59 \mathrm{~d}$ after emergence in their early May sowing date, was attained about $43 \mathrm{~d}$ after emergence in their later May sowing date. Thus, node appearance in the latter was about $5 \mathrm{~d}$ behind that in the former. Node production did cease at the beginning of seed-fill (reproductive stage R5) in both planting dates.
Fehr and Caviness (1977) stated that from emergence to the fifth node, a new node appeared on the main stem about every $5 \mathrm{~d}$, but also noted that this could vary from 3 to $8 \mathrm{~d}$. They also noted that after node 5 , a new node appeared on the main stem about every $3 \mathrm{~d}$, but again noted that this could range from 2 to $5 \mathrm{~d}$, depending on the temperature. The foregoing numbers have been restated many times since then (Monks et al., 1988; Pedersen, 2004), although these generalizations are often misinterpreted by producers.

Zhang et al. (2004) reported on a 5-yr field study in Mississippi in which the calendar dates of successive main stem nodes were recorded every other day for cultivars ranging from maturity group (MG) early or mid-3 to late 5 grown in early March to late June planting dates. The difference in days between planting and emergence (VE) ranged from a high of $14 \mathrm{~d}$ for all cultivars in the early (cooler) March planting date to a low of $5 \mathrm{~d}$ in the (warmer) mid-May to late June plantings. The respective differences in development at other stages ranged from 16 to $5 \mathrm{~d}$ from $\mathrm{VE}$ to $\mathrm{VC}(=\mathrm{V} 0), 6$ to $5 \mathrm{~d}$ from V0 to V1, 6 to $4 \mathrm{~d}$ from V1 to $\mathrm{V} 2$, and 5 to $3 \mathrm{~d}$ for each successive node thereafter.

Aside from the foregoing Mississippi study, studies where the measurement period for V-node and R-stage assessment was as short or shorter than the period between node appearance, as recommended by McMaster and Hunt (2003), are not available in the literature. This is also true for western Corn Belt locations where irrigation is practiced.

The objective of our study was to quantify the impact of planting date on the vegetative, reproductive, and agronomic performance of $14 \mathrm{MG} 3.0$ to 3.9 cultivars planted at about 16-d intervals over a 7 -wk span during which Nebraska producers typically plant such cultivars. These data and those for yield and other measured agronomic variables were collected in an east-central Nebraska irrigated production system that was optimally managed to allow expression of the available seed yield potential (Specht et al., 1999, 2006).

\section{MATERIALS AND METHODS}

A 2-yr field experiment was conducted in 2003 and 2004 on the Agronomy Farm at the East Campus of the University of Nebraska, Lincoln $\left(40^{\circ} 51^{\prime} \mathrm{N}, 96^{\circ} 45^{\prime} \mathrm{W}\right)$ on a deep Kennebec silt loam soil (fine-silty, mixed, superactive, mesic Cumulic Hapludoll). The previous crop each year was maize (Zea mays L.). The field was fall-plowed after maize harvest, then fieldcultivated twice in the spring of each year.

The experimental design each year was a split-plot randomized complete block with four replicates (i.e., blocks). Main plots were four planting dates scheduled each year at about 16-d intervals. In 2003, those dates were 2 May (day of year [DOY] 122), 17 May (137), 30 May (150), and 16 June (167), but in 2004 were 28 April (119), 16 May (137), 2 June (154), and 17 June (169). Subplots were 14 soybean cultivars of MG 
3.0 to 3.9, which is the MG range recommended for the latitude of this test location. The 14 cultivars were selected from the highest yielding entries in 2- or 3-yr performance trials conducted before 2003 in Nebraska and Iowa. These cultivars were Asgrow AG3401 (relative maturity 3.4); Dekalb DKB 31-52 (3.1); Kaup 335 (3.3); Kruger K323+RR (3.2); Latham 1067RR (3.1); Nebraska strains NE3001 (3.0), NE3201 (3.1), and NEX8903 (3.1); Nebraska experimental lines U98-307162 (3.4), U98-307917 (3.4), and U98-311442 (3.9); Pioneer 93B36 (3.3) and 93B47 (3.4); and Stine 3632-4 (3.6). All were indeterminate, except for the semideterminate cultivar NE3001. High quality, fungicide-treated seed was obtained from the Nebraska Seed Foundation or from the indicated companies. The fourrow subplot row length was $4.3 \mathrm{~m}$, with an interrow spacing of $0.76 \mathrm{~m}$. The viable seeding rate was 390,000 seeds $\mathrm{ha}^{-1}$ and the sowing depth was $2.5 \mathrm{~cm}$.

In 2003, weed controlwasaccomplished witha preplantapplication of $0.03 \mathrm{~kg} \mathrm{ha}^{-1}$ of flumetsulam $\{\mathrm{N}$-(2,6-difluorophenyl)5-methyl-[1,2,4]-triazolo-[1,5a]-pyrimidine-2-sulfonamide $\}$ and $1.07 \mathrm{~kg} \mathrm{ha}^{-1}$ of s-metolachlor \{2-chloro-N-(2-ethyl6-methylphenyl)-N-[(1S)-2-methoxy-1-methylethyl]acetamide\}. In 2004, the preplant application was $0.23 \mathrm{~kg} \mathrm{ha}^{-1}$ of flufenacet $\{\mathrm{N}$-(4-fluorophenyl)-N-(1-methylethyl)-2-[[5(trifluoromethyl)-1,3,4-thiadiazol-2-yl]oxy]acetamide\} and $0.06 \mathrm{~kg} \mathrm{ha}^{-1}$ of metribuzin [4-amino-6-(1,1-dimethylethyl)-3(methylthio)-1,2,4-triazin-5(4H)-one]. Irrigation was applied with a solid set sprinkler system. Except for a light irrigation immediately after the first planting date in 2004 (due to dry soil conditions), irrigation was not needed until late June, and was scheduled as needed to routinely replenish soil moisture with adjustments made for local rainfall and crop daily evapotranspiration (ET). The Penman-Monteith equation (Allen et al., 1998) was used to estimate daily ET from air temperature, radiation, humidity, and wind speed data collected from a nearby automated weather station operated by the High Plains Regional Climate Center (http://www.hprcc.unl.edu).

The data collected from the central two rows of each four-row subplot included plant maturity (days from planting to maturity; i.e., when $95 \%$ of the pods are mature); mature (standing) plant height, measured from the ground surface to the tip of the main stem; plant population, based on a plant count in a $4.3-\mathrm{m}$ section of a one subplot row (at maturity in both years and just after emergence in 2004); seed yield, based on the weight and moisture of the seed harvested with a 2-row plot combine with the final yield adjusted to $13 \%$ seed moisture; and 100-seed weight, based on the weight of a sample of 100 random seeds (also adjusted to 13\% moisture). A 75-g sample of the harvested seed of each subplot was subjected to a nearinfrared analysis to estimate seed protein and oil content at 13\% seed moisture. Two representative plants per subplot were gathered at harvest to obtain a two-plant mean measure of the final length of each internode, starting with internode one located between the cotyledonary node (V0) and unifoliolar node (V1), and ending with the last visible internode between the last two nodes at the tip of the stem.

The soybean V- and R-staging system described by Fehr et al. (1971) was used to track plant development in each of the 14 cultivars in each of the planting dates. For readers unfamiliar with this system, a V-number is assigned to a given stem node $(\mathrm{Vn})$ on the calendar date when leaflets at the next node above $(\mathrm{Vn}+1)$ have just unrolled so that their edges are no longer touching. Sinclair (1984b) noted that leaflets meeting this "just unrolled" criterion were $21 \mathrm{~mm}$ in length. Reproductive development in each planting date of each year was tracked using the R1 (begin flower), R2 (full flower), R3 (begin pod), R4 (full pod), R5 (begin seed), R6 (full seed), R7 (begin maturity), and R8 (full maturity) stages defined by Fehr et al. (1971). Plant development was scored biweekly to match an anticipated 3- to 5-d node appearance rate, as recommended by McMaster and Hunt (2003). On each biweekly scoring date, 10 adjacent plants were individually scored to obtain 10-plant mean values for $\mathrm{Vn}$ and $\mathrm{Rn}$ development, as recommended by Fehr and Caviness (1977). The time interval between the appearance of two successive leaves on the main stem is known as a phyllochron (Wilhelm and McMaster, 1995; McMaster and Hunt, 2003; Hunt et al., 2003), not a plastochron (Hofstra et al., 1977). By botanic definition, the latter term is restricted to the time period between successively initiated leaf primordia (Erickson and Michelini, 1957), which can only be observed via daily microscopic dissection and observation of a main stem apical meristem (Miksche, 1961).

All agronomic data and the final main stem node and internode length data were subjected to an analysis of variance, using the PROC MIXED (Littell et al., 1996) procedure of SAS (SAS Institute, 1999). Only planting date was considered a fixed effect, so the RANDOM statement included the terms year, block (year), year $\times$ planting date, block $\times$ planting date (year), cultivar, year $\times$ cultivar, planting date $\times$ cultivar, and year $\times$ planting date $\times$ cultivar. The MODEL statement included a DDFM = KR option to specify a Kenward-Roger adjustment in the computation of a Satterthwaite-type denominator degrees of freedom (Ddf) for the evaluation of mixed model effects. ESTIMATE statements were used to compute the means and standard errors of main effects and interactions. CONTRAST statements were used to partition the planting date mean square into preplanned single-degree-of-freedom mean squares attributable to the linear, quadratic, and cubic effects. A Type 1 error value of $\alpha=0.05$ was chosen as the $F$-test significance criterion.

The observably triphasic seasonal pattern of seasonal V-node appearance in each of the eight planting dates was fit to a three-segment linear regression model. This model was chosen because five of its six estimable parameters (i.e., the B1, $\mathrm{B} 2$, and $\mathrm{B} 3$ regression coefficients for the three successive linear phases, with the $\mathrm{X} 0$ and $\mathrm{X} 1$ breakpoints separating the linear phases) have biological meaning. The sixth parameter (I1) is the $\mathrm{y}$-intercept when $\mathrm{X}=0$, and it was set to an arbitrary V-node value of -2.0 to represent the day of planting. The Fehr and Caviness (1977) system uses the term VE to denote seedling emergence, but in this study, we assigned this stage an arbitrary $\mathrm{V}$-node value of -1.0 . These assignments were necessary to retain monotonicity in $\mathrm{V}$-node stage from planting onward, thus avoiding the awkward "hidden stage" parameter that Pachepsky et al. (2002) devised to deal with pre-V0 vegetative development. Model-fitting was implemented with GraphPad Prism 4 software (Motulski and Christopoulos, 2003) using this (componentized) GraphPad equation: Y1 $=\mathrm{I} 1+\mathrm{B} 1 \times \mathrm{X}$, Y at 
$\mathrm{X} 0=\mathrm{I} 1+\mathrm{B} 1 \times \mathrm{X} 0, \mathrm{Y} 2=\mathrm{Y}$ at $\mathrm{X} 0+\mathrm{B} 2 \times(\mathrm{X}-\mathrm{X} 0), \mathrm{Y}$ at $\mathrm{X} 1$ $=\mathrm{Y}$ at $\mathrm{X} 0+\mathrm{B} 2 \times(\mathrm{X} 1-\mathrm{X} 0), \mathrm{Y} 3=\mathrm{Y}$ at $\mathrm{X} 1+\mathrm{B} 3 \times(\mathrm{X}-\mathrm{X} 1)$, and $\mathrm{Y}=\mathrm{IF}(\mathrm{X}<\mathrm{X} 0, \mathrm{Y} 1, \mathrm{IF}(\mathrm{X}<\mathrm{X} 1, \mathrm{Y} 2, \mathrm{Y} 3))$. Model-fitting was robust when suitable initial values were supplied for the five estimable parameters, and $R^{2}$ values of 0.996 or better were achieved for the fits in each of the eight data sets. Attempts to globalize the model parameter fits to all planting dates are described in the Results section.

The length of each successive internode on a mature main stem exhibited a parabolic-like pattern when plotted as a function of nodal position (after node 3, since internode length declined from node 0 to 3 ). This led us to model the data for each planting date with a three-parameter Lorentzian function: $\mathrm{Y}=\mathrm{A} /\left\{1+[(\mathrm{X}-\mathrm{C}) /(\mathrm{W})]^{2}\right\}$, where $\mathrm{C}$ is the centering $\mathrm{X}$ value at which the Lorentzian peak attains its greatest amplitude (A), and $\mathrm{W}$ is the peak half-width when measured at peak halfamplitude. These parameters had biological meaning relative to hypotheses as to whether planting date delays (and thus the accompanying warmer temperatures) would shift the peak of internode length to a lower node, or increase peak amplitude, or lessen its width, or any combination of these. The global fitting efforts are described in the Results section.

Soybean reproductive development is characterized by changes in organ morphology that are qualitative, not quantitative, despite the assignment of consecutive integers (i.e., 1-8) to the successive $\mathrm{R}$ stages. The $\mathrm{R}$-stage trend in each planting date had an irregular pattern that could not be fit to a simple mathematical model whose parameters had intrinsic biological meaning. However, the focus in the present paper was determining the coincidence of key R-stages with the dates of key phases in the modeled patterns of node accrual and internode length. With that in mind, a nonlinear "standard curve" was generated for each planting date by fitting the R-stage data to the best-fitting polynomial equation (as described by Motulski and Christopoulos, 2003). An F-test was used to determine if the gain in model $R^{2}$ generated when a polynomial of a given order was incremented to its next higher order was due to chance. A quintic (i.e., fifth order) polynomial was judged by such $F$-tests to sufficiently account for most of the nonlinearity present in each R-stage data set.

A. 2003
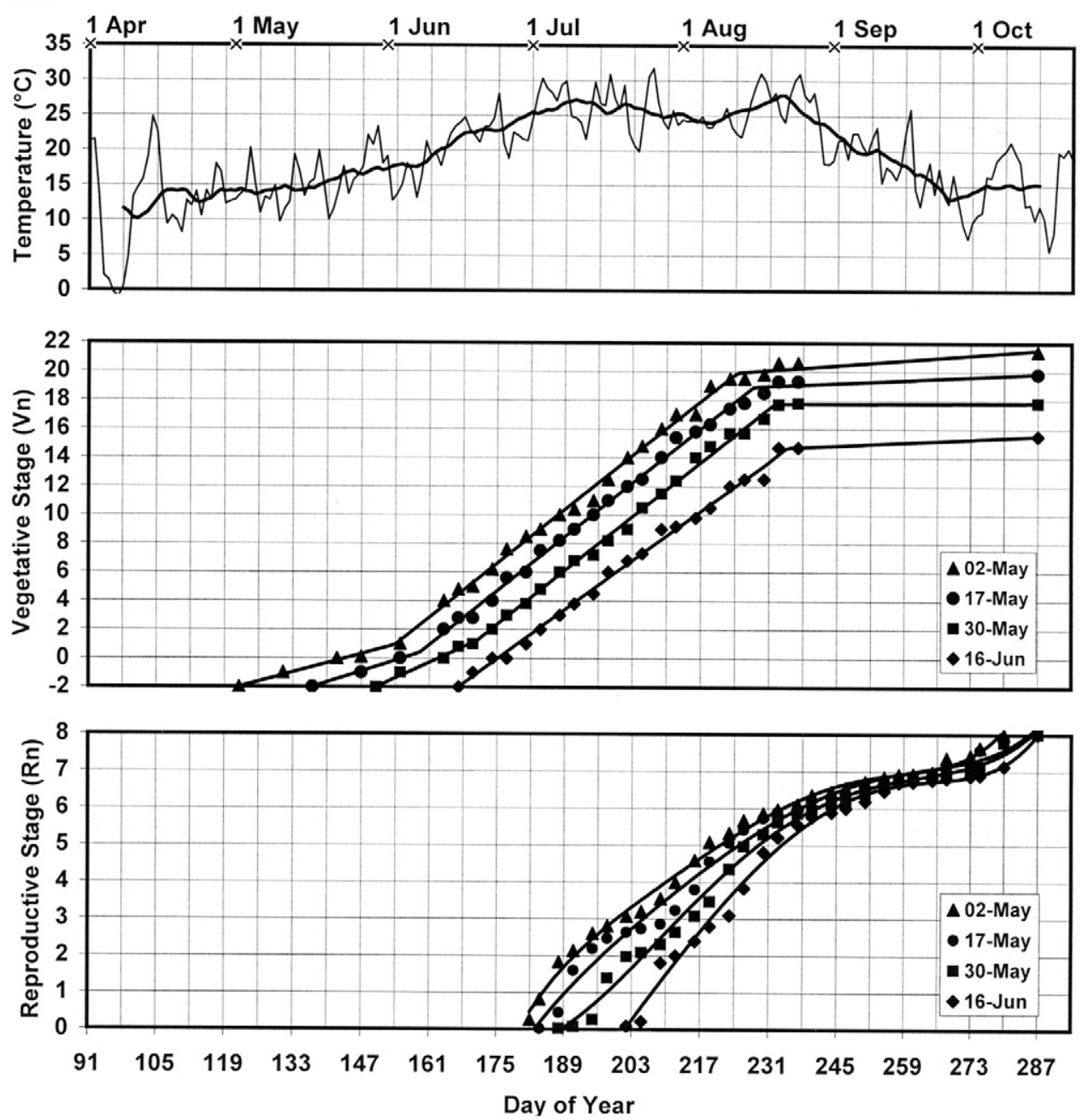

Figure 1. Temperature and phenological data for (A) 2003; (B) 2004. Top: Daily (thin line) and 15-d (thick line) mean temperatures from Day 91 to 294 on a day of year (DOY) scale. Middle: Progression of biweekly vegetative node number (Vn) in each planting date. Vn values of -2 and -1 were arbitrarily used to denote the sowing and emergence (VE) stages. Bottom: Progression of biweekly reproductive stage (Rn) number in each planting date. The staging system of Fehr and Caviness (1977) was used. Each V-and R-stage data symbol represents a mean of 140 plants. 


\section{RESULTS}

Seasonal temperature and rainfall patterns in the two experimental seasons were quite different (Table 1). In 2003, July and August were $3^{\circ} \mathrm{C}$ warmer, May and September were $3^{\circ} \mathrm{C}$ cooler, and June was $1.5^{\circ} \mathrm{C}$ cooler than those same months in 2004 . Seasonal temperatures in 2003 followed the historical pattern, rising steadily from May to June to July at a rate of $5^{\circ} \mathrm{C}$ per month, holding at $26^{\circ} \mathrm{C}$ in July and August, and then declining sharply from August to September (Fig. 1). In contrast, the 2004 seasonal temperature pattern had less in-season variation, with May, June, and September warmer, but July and August cooler, than their historical means.

Rainfall during the growing season (MaySeptember) totaled to $378 \mathrm{~mm}$ in 2003 and 359 $\mathrm{mm}$ in 2004 (Table 1). However, after a rainy June of 2003, rainfall was limited during July and August. Daily crop ET was also greater in these two abnormally warm months, making more frequent irrigation necessary. In fact, all irrigation needed in $2003(250 \mathrm{~mm})$ was applied during these 2 mo. Less irrigation was needed in 2004 $(161 \mathrm{~mm})$, due to the cooler temperatures that year that
Table 1. Precipitation, irrigation, and temperature on a monthly and seasonal basis during 2003 and 2004 at the Agronomy Farm on the East Campus of the University of Nebraska at Lincoln.

\begin{tabular}{lrrrrrc}
\hline \multicolumn{1}{c}{ Variable and year } & May & June & July & August & September & Season \\
\hline Temperature & & & & & & Mean \\
2003, ${ }^{\circ} \mathrm{C}$ & 15.5 & 20.4 & 26.4 & 25.5 & 17.3 & 21.0 \\
2004, ${ }^{\circ} \mathrm{C}$ & 18.3 & 21.8 & 23.2 & 22.7 & 20.6 & 21.3 \\
Historic (1989-2004), ${ }^{\circ} \mathrm{C}$ & 17.1 & 22.5 & 25.2 & 24.2 & 19.4 & 21.7 \\
Precipitation & & & & & & Total \\
2003, mm & 70.0 & 162.6 & 25.0 & 36.3 & 84.2 & 378.1 \\
2004, mm & 123.9 & 64.3 & 71.3 & 36.1 & 63.5 & 359.1 \\
Historic (1989-2004), mm & 114.4 & 90.2 & 83.7 & 72.1 & 61.9 & 422.2 \\
Irrigation & & & & & & Total \\
2003, mm & 0.0 & 0.0 & 101.6 & 148.6 & 0.0 & 250.2 \\
2004, mm & 31.8 & 35.6 & 38.1 & 27.9 & 27.9 & 161.3 \\
\hline
\end{tabular}

reduced daily crop ET during the critical July-August reproductive growth period.

\section{Vegetative and Reproductive Development}

Vegetative and reproductive development data for individual cultivars within each planting date were utilized and presented in Setiyono et al. (2007), so only the planting

B. 2004
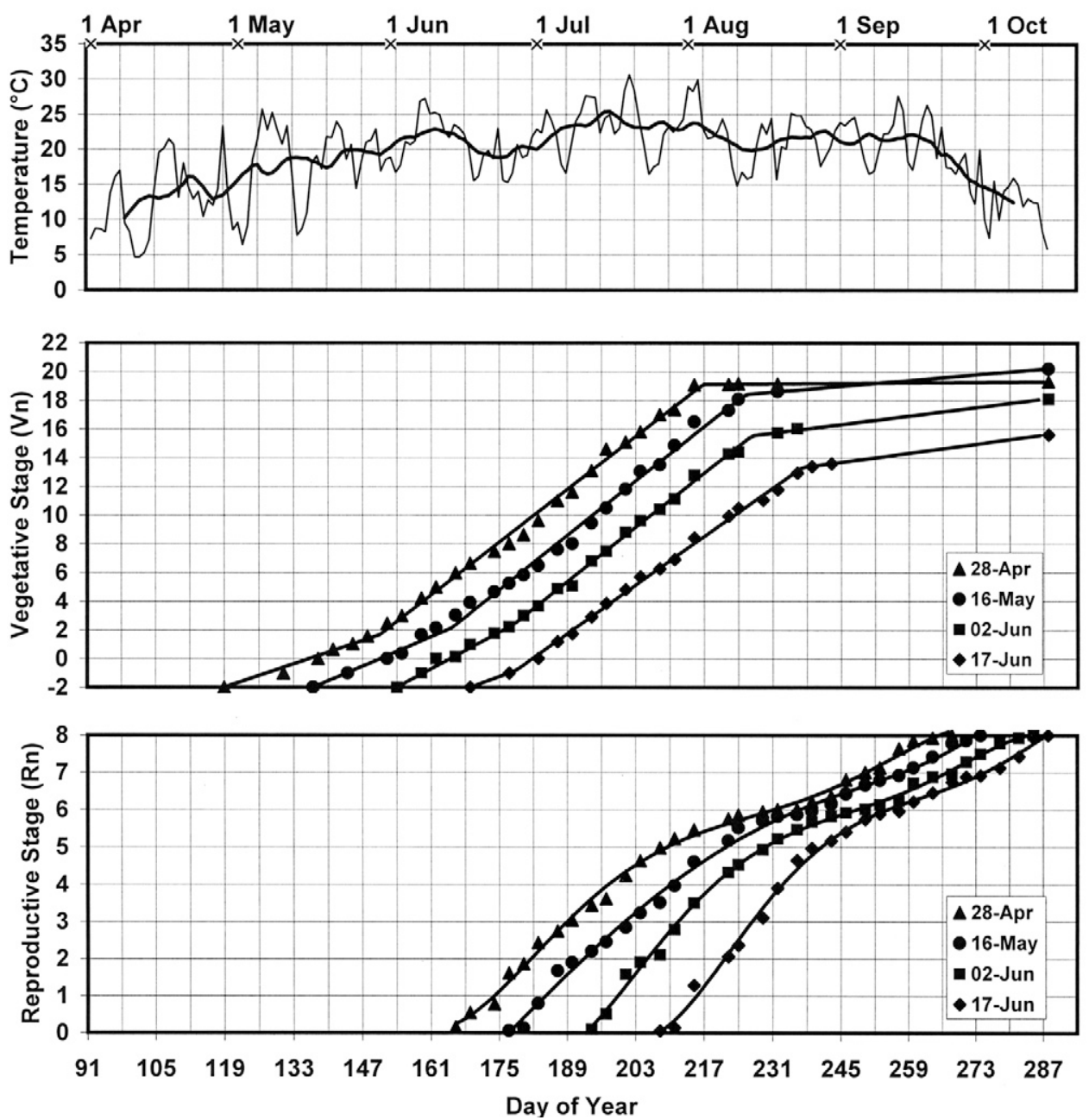

Figure 1. Continued. 
Table 2. Trisegment linear regression model fits and parameter estimates for the 2003 and $2004 \mathrm{~V}$-stage vs. days after planting (DAP) data collected in the four planting dates shown in Fig. 2. The R-stage DAP estimates were interpolated from the polynomial R-stage curves as described in the text.

\begin{tabular}{|c|c|c|c|c|c|c|c|c|c|c|c|c|c|c|}
\hline \multirow[t]{4}{*}{$\begin{array}{l}\text { Date of } \\
\text { planting }\end{array}$} & \multirow[t]{4}{*}{$\begin{array}{l}\text { No. of } \\
\text { obs. }\end{array}$} & \multicolumn{4}{|c|}{ Global fits for a model } & \multirow{2}{*}{\multicolumn{2}{|c|}{$\begin{array}{l}\text { Model fits } \\
\text { with a fixed } \\
\text { B2 and X0 }\end{array}$}} & \multicolumn{6}{|c|}{$\begin{array}{c}\text { Trisegment linear regression } \\
\text { model with } 5 \text { parameters }{ }^{\dagger}\end{array}$} & Time required to attain stages \\
\hline & & \multicolumn{2}{|c|}{ with a shared B2 } & \multicolumn{2}{|c|}{ plus a shared $\mathrm{XO}$} & & & Est. & B1 & B2 & B3 & $\mathrm{xO}$ & $\mathrm{X} 1$ & V1 R0 R1 R2 R3 R4 R5 R6 R7 R8 \\
\hline & & df & $R^{2}$ & $\mathrm{df}$ & $R^{2}$ & df & $R^{2}$ & & $-n$ & hode $d$ & $-1-$ & - & 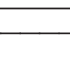 & DAP \\
\hline & & & & & & & & $\mathrm{L}$ & 0.089 & 0.264 & 0.009 & 30 & 101 & \\
\hline \multirow[t]{3}{*}{2 May 2003} & 28 & 131 & 0.998 & 50 & 0.998 & 25 & 0.998 & $E$ & 0.095 & 0.268 & 0.025 & 32 & 103 & 32556370798898112139158 \\
\hline & & & & & & & & U & 0.100 & 0.272 & 0.041 & 35 & 105 & \\
\hline & & & & & & & & L & 0.110 & & 0.000 & & 95 & \\
\hline \multirow[t]{3}{*}{28 Apr. 2004} & 29 & - & - & - & - & 26 & 0.997 & E & 0.115 & $\ddagger$ & 0.003 & $\neq$ & 97 & 26465462707991111131146 \\
\hline & & & & & & & & U & 0.120 & & 0.017 & & 99 & \\
\hline & & & & & & & & $\mathrm{L}$ & 0.117 & & 0.001 & 20 & 89 & \\
\hline \multirow[t]{3}{*}{17 May 2003} & 26 & - & - & 44 & 0.997 & 23 & 0.998 & E & 0.123 & $\neq$ & 0.015 & 24 & 91 & 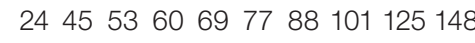 \\
\hline & & & & & & & & $u$ & 0.130 & & 0.030 & 28 & 93 & \\
\hline & & & & & & & & L & 0.140 & & 0.053 & & 93 & \\
\hline \multirow[t]{3}{*}{16 May 2004} & 25 & - & - & - & - & 22 & 0.996 & E & 0.131 & $\neq$ & 0.029 & $\neq$ & 89 & $23374856 \quad 6473 \quad 84101120136$ \\
\hline & & & & & & & & u & 0.123 & & 0.005 & & 84 & \\
\hline & & & & & & & & L & 0.153 & & 0.000 & 18 & 81 & \\
\hline \multirow[t]{3}{*}{30 May 2003} & 25 & - & - & 41 & 0.998 & 22 & 0.998 & E & 0.160 & $\neq$ & 0.001 & 22 & 82 & 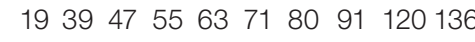 \\
\hline & & & & & & & & u & 0.167 & & 0.017 & 25 & 84 & \\
\hline & & & & & & & & L & 0.170 & & 0.030 & & 71 & \\
\hline \multirow[t]{3}{*}{2 June 2004} & 23 & - & - & - & - & 20 & 0.998 & E & 0.177 & $\neq$ & 0.043 & $\neq$ & 73 & $173945 \quad 51586576 \quad 94 \quad 113130$ \\
\hline & & & & & & & & u & 0.183 & & 0.055 & & 75 & \\
\hline & & & & & & & & L & 0.228 & 0.233 & 0.000 & 3 & 65 & \\
\hline \multirow[t]{3}{*}{16 June 2003} & 322 & 33 & 0.997 & 35 & 0.997 & 19 & 0.996 & E & 0.247 & 0.243 & 0.016 & 10 & 68 & $12 \quad 3540 \quad 46525967 \quad 77 \quad 110120$ \\
\hline & & & & & & & & u & 0.267 & 0.253 & 0.038 & 17 & 72 & \\
\hline & & & & & & & & L & 0.111 & & 0.033 & & 66 & \\
\hline \multirow[t]{2}{*}{17 June 2004} & +20 & - & - & - & - & 17 & 0.998 & E & 0.124 & $\neq$ & 0.046 & $\neq$ & 68 & 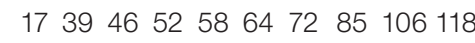 \\
\hline & & & & & & & & $\mathrm{u}$ & 0.136 & & 0.059 & & 70 & \\
\hline
\end{tabular}

${ }^{\dagger} E$, estimate of the model parameter; $L$, lower limits of its $95 \%$ confidence interval; $U$, upper limits of its $95 \%$ confidence interval.

‡Based on global model fitting, E, L, U values for this planting date were identical to the $E, L, U$ values for the above-listed planting date.

date data will be presented in this paper. The seasonal daily temperature patterns, and the vegetative V-stage and reproductive R-stage trends vs. DOY in each planting date are shown together (for context) as the top, middle, and bottom graphs in Fig. 1A (2003) and Fig. 1B (2004). The near-linearity of node appearance in each planting date that is apparent in the middle Fig. 1 graphs was a surprising contradiction of the often-repeated Fehr and Caviness (1977) statement that node appearance changes from a 5-d interval to a 3-d interval at about V5. Moreover, node accrual trends for the planting dates were nearly parallel, despite a temperature rise from early May to mid-July that was expected to result in more rapid node accrual in later planting dates.

A trisegment linear regression model provided good fits $\left(R^{2}>0.99\right)$ to the triphasic patterns of node accrual in each planting date of each year (Fig. 2). Attempts to fit a global model to all eight data sets were not successful, as low probabilities $(P>0.0001)$ were obtained for the $F$-tests of the null hypothesis that a common value for all or any one of the five model parameters was shared in all eight data sets. However, a global model of a shared central slope $\left(\mathrm{B} 2=0.268\right.$ nodes $\left.\mathrm{d}^{-1}\right)$ did fit the six data sets comprising the first three planting dates $\left(F_{5,126}=0.45\right.$; $P=0.82)$, and a global model of a shared central slope of smaller magnitude $\left(\mathrm{B} 2=0.243\right.$ nodes $\mathrm{d}^{-1} ; F_{1,32}=0.20$; $P=0.65)$ also fit the two data sets of the last planting date (Fig. 2). Parameter estimates and their confidence intervals for these and subsequently presented model fits are provided in Table 2 . A shared X0 parameter fit of the 2003 and 2004 data sets within each planting date generated estimates of 32, 24, 22, and $10 \mathrm{DAP}$ for the X0 parameter for the earliest to the latest planting dates (Fig. 2, Table 2), based on respective F-tests (i.e., Ddf of 49, 43, 40, and 34; ratios of $0.11,2.51,0.83$, and 0.21 ) that had probabilities of $0.75,0.12,0.47$, and 0.65 . A shared fit of the B1 slope parameter was not supported by F-tests, mainly because B1 increased as planting was delayed, and those increases were larger in 2004 than in 2003, except in the last planting. Confidence intervals revealed that the X1 breakpoint parameter (which declined in magnitude as planting was delayed) was shared by the 2003 and 2004 data sets within 
the mid-May and mid-June planting dates, but not within the earliest and late May planting dates. The B3 slope parameter estimates were low and near-zero in many of the eight data sets.

Reproductive development displayed nonlinear patterns of response to sowing date, with those in 2003 (Fig. 1A) observably different from those in 2004 (Fig. 1B). Modern soybean crop models typically undergo continual updating to make the prediction of reproductive development less empirical and more mechanistic (Boote et al., 2003; Setiyono et al., 2007). However, the goal in the present paper was simply to relate the observed R-stage integers to key parameters and phases in the vegetative node accrual and internode length models. To that end, a best-estimate of the DAP value for each R-stage integer in each planting date was derived by empirical interpolation from the standard curves created by fitting the eight R-stage development vs. DAP data sets to a quintic polynomial regression model. Global model fitting revealed that a good fit of the equation to all four 2003 R-stage data sets could be achieved with a shared y-intercept parameter $\left(F_{3,86}=1.89 ; P=0.14\right)$. This was also true for all four 2004 data sets $\left(F_{3,82}=2.64 ; P=0.055\right)$, though the shared y-intercept differed in magnitude from that of the prior year. Additional global fitting was not successful due to the low probabilities of the corresponding F-tests. The polynomial model fits for this one-time generation of 2003 and 2004 standard curves would not be useful for R-stage prediction in other years (a more sophisticated crop model should be used for that purpose), so a graph of the polynomial curves and a table of parameter values are not presented here. The interpolated DAP values corresponding to each $\mathrm{R}$-stage in each planting date are tabulated in Table 2, with some also depicted in Fig. 2. Extrapolation of R-stage to a y-intercept of zero generated a DAP (in Table 2) value that we have arbitrarily designated as R0.0 to describe the stage at which at least one plant (of the population) would be expected to flower the next day. Such a term is consistent with use of the R0.1 or R0.9 terms that Fehr and Caviness (1977) suggested using if 1 or 9 of 10 total plants had flowered.

Internode length means at each successive node position are shown in Fig. 3. The PROC MIXED analyses revealed that the length of nearly every internode was significantly influenced by planting date, year $\times$ planting date, and cultivar, though the two- and three-way cultivar interactions were surprisingly not significant, except at high node positions (due to cultivar differences in final node number). A biologically meaningful analysis of the impact of planting date was achieved by modeling the parabolic-like change in internode length vs. nodal position (after node 3 ) as a Lorentzian curve (Fig. 4). A global model of shared peak amplitude $(A=8.54$ $\mathrm{cm})$ provided a surprisingly good fit to all eight data sets
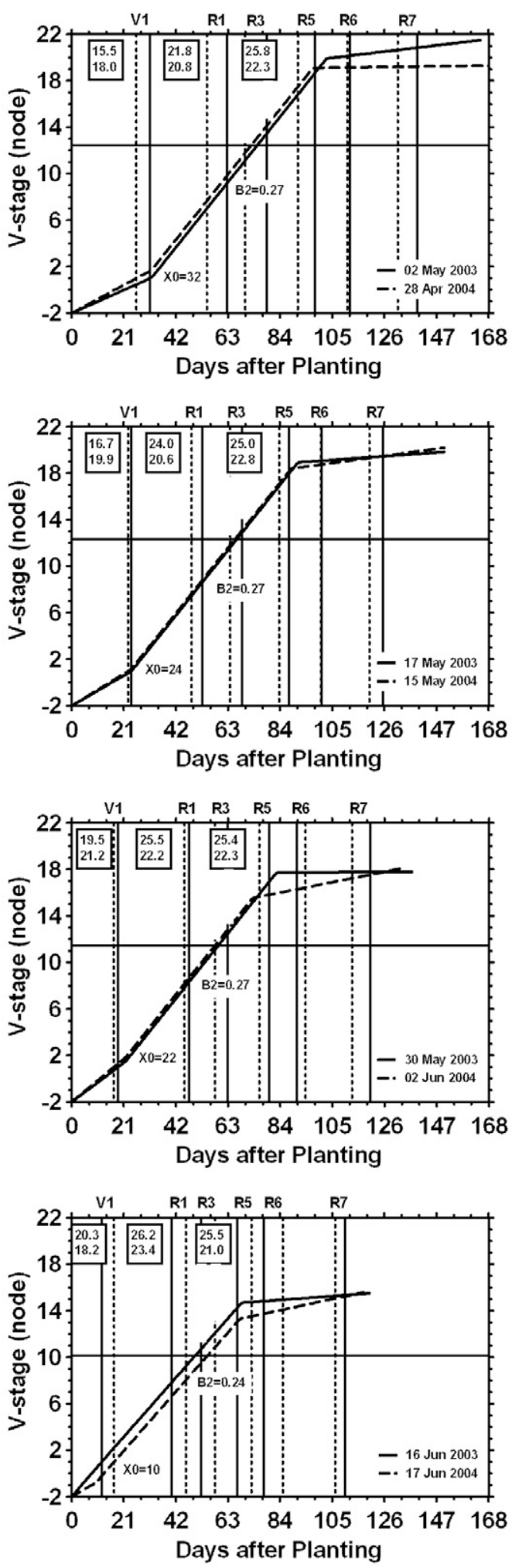

Figure 2. Fits of a trisegment linear regression model to the triphasic $\mathrm{V}$-stage data shown in Fig. 1 for the four planting dates in 2003 (solid lines) and 2004 (dashed lines). The vertical lines denote the coincident day after planting (DAP) values for $\mathrm{V} 1$ and some key $R$ stages. Estimates for all five model parameters and the DAP values for all $R$ stages, are listed in Table 2. The text boxes show the average air temperature $\left({ }^{\circ} \mathrm{C}\right.$ ) in 2003 (top number) and 2004 (bottom) during the time intervals demarked by the V1, R1, and R5 vertical lines. The horizontal line denotes the stem node number coincident with the peak center parameters of the internode length models (Fig. 4). 
$\left(F_{7,149}=0.63 ; P=0.73\right)$, suggesting that the length of the longest main stem internode was not impacted by planting date or by year. Global fitting was not possible with the other two parameters, though model fits with yearshared values for the peak center parameter and the peak width parameter were obtained, based on F-tests (with numerator degrees of freedom $[\mathrm{Ndf}]=2$, respective $\mathrm{Ddf}$ numbers of $43,42,37$, and 35 , and ratios of $0.67,0.81$, 0.88 , and 0.96 ) that had probabilities of $0.51,0.45,0.42$, and 0.39 for the respective succession of sowing dates. As planting was delayed, the nodal position of the longest internode shifted from 12 to 10 .

\section{Agronomic Traits}

Planting date had a significant linear impact on final node number at maturity (Table 3), as shown in Fig. 1 (far-right

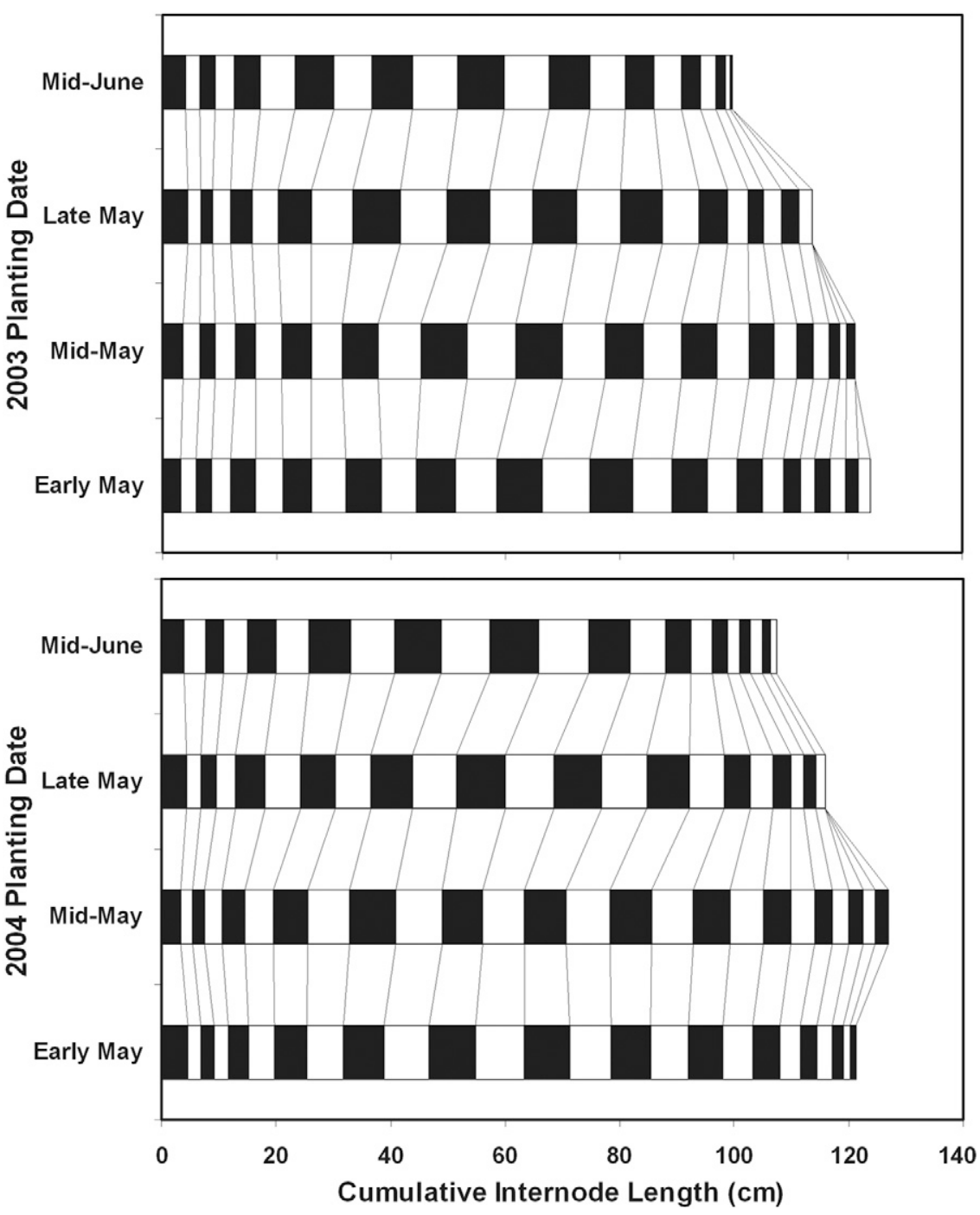

Figure 3. Mature internode lengths in each of the four planting dates of 2003 and 2004. The beginning (i.e., first) internode, which is located between the cotyledonary node (VO) and unifoliolar node (V1), is symbolized by the leftmost solid-fill section of each bar. Thereafter, alternating open and solid sections of each bar symbolize even- and odd-numbered internodes, whose length in each bar is a mean of two plants, 14 cultivars, and four replicates (i.e., $n=112$ ). For comparability, thin lines connect the same internode across the four planting dates. data; middle graphs), producing about 0.13 to 0.14 fewer nodes per day of sowing delay. However, the magnitude of the linear response differed between years, and an unexpected rank reversal in final node number between the first and second sowing dates in 2004 generated a quadratic response in that year. This led to a significant year $x$ planting date interaction. The trend of later sowing dates leading to fewer final nodes was observed for every cultivar, though a significant (linear only) planting date $\times$ cultivar interaction arose because cultivars with a genetic predisposition for greater node numbers displayed a larger nodal decline over planting dates (i.e., from 20 to 15 for Kruger K323+RR, but only 18 to 15 for NE3001).

Standing plant height at maturity was lengthened by a total of $19 \mathrm{~cm}$ when planting was advanced $7 \mathrm{wk}$ from mid-June to early May (Fig. 5A). Although the linear effect in the response to planting date did not differ between years, the quadratic effect was greater in 2004, leading to a year $\times$ planting date interaction (Table 3). Plants in earlier plantings had more final stem nodes (except in early 2004), but also had shorter internodes in the $\mathrm{V} 3$ to $\mathrm{V} 9$ region of the stem (Fig. 3, 4). These two offsetting effects accounted for some of the nonlinear response of plant height to sowing date (Fig. 5A). The planting date $\times$ cultivar interaction was not significant for plant height, even though this group of cultivars had heights ranging from $85 \mathrm{~cm}$ for the semideterminate NE3001 to $120 \mathrm{~cm}$ for the indeterminate AG3401.

Our goal of achieving the same plant density among cultivars at maturity in each year of this experiment (by adjusting their seeding rates for differences in seed viability) was not entirely successful, given the statistical significance of the cultivar effect and its interaction with years (Table 3). Seedling emergence in earlier (cooler) plantings is frequently lower than that in later plantings (Oplinger and Philbrook 1992). Our 2003 data fit this scenario, but our 2004 data did not, probably because of the warm spring in 2004, resulting in a significant planting date $\times$ year interaction of the crossover type (Fig. 5B). However, this interaction did not have much impact on internode length, given that the 2003 and 2004 data sets of internode length in each planting date could be modeled using common values for all three parameters of the Lorentzian model (Fig. 4). In 2004, plant density was examined at both emergence and maturity, and these two exhibited near-parallel response patterns as 
planting was delayed, with about 40,000 fewer plants $\mathrm{ha}^{-1}$ at harvest than at emergence in each planting date (Fig. 5B). So, about $10 \%$ of the emerged seedlings in each sowing date did not survive to be counted at maturity. The significant cultivar differences in plant density were not correlated with cultivar yield $(r=-0.10)$.

Planting date and its interaction with year were significant for R8 plant maturity date (Table 3). The difference in $\mathrm{R} 8$ plant maturity from the first to the last planting date was about $25 \mathrm{~d}$ in 2003 and about $40 \mathrm{~d}$ in 2004 (Fig. 1, far right, bottom graphs). Days from sowing to plant maturity declined linearly by $0.9 \mathrm{~d}$ per day of planting date delay in 2003 , but only by $0.5 \mathrm{~d}$ per day of delay in 2004 (data not shown). This strong downward trend in plant maturity relative to sowing date delay was also observed for each cultivar (i.e., no planting date $\times$ cultivar interaction). However, the within planting date ranking of cultivar maturity was not consistent over planting dates and years (except for the earliest and latest maturing cultivars), which resulted in a significant year $\times$ cultivar and three-way interaction. Among these MG 3.0 to 3.9 cultivars, mean plant maturity spanned a 5-d interval, ranging from 129 $\mathrm{d}$ for NE3001 (3.0) to $134 \mathrm{~d}$ for AG3401 (3.4). The rela-

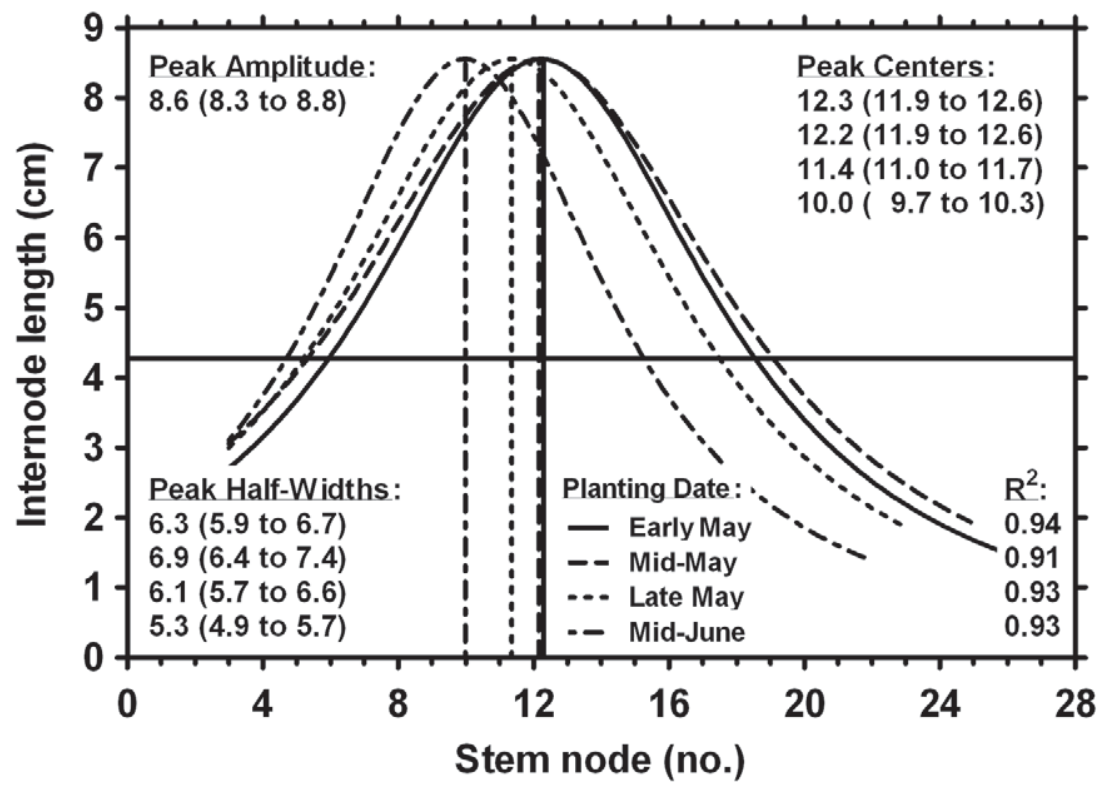

Figure 4. Lorentzian model fits to the mature internode length data in each of the four planting dates. Estimates and 95\% confidence intervals for the three model parameters are depicted in the graph, along with $R^{2}$ values. For each planting date, the vertical line connects the peak center of amplitude (i.e., longest internode) to its corresponding main stem node number. The horizontal line reflects the peak half-amplitude value, at which the peak half-width (nodal) values apply.

Table 3. F-test numerator and denominator degrees of freedom (Ndf and Ddf, respectively) and probability values obtained in the PROC MIXED analysis of variance of the indicated traits for the year, planting date, and cultivar effects, and their interactions, in the 2003-2004 planting date experiment. Contrasts were used to estimate the linear, quadratic, and cubic components of the planting date effect and its interaction with year.

\begin{tabular}{|c|c|c|c|c|c|c|c|c|c|c|}
\hline $\begin{array}{c}\text { ANOVA } \\
\text { source of variation }\end{array}$ & Ndf & Ddf & $\begin{array}{l}\text { Mature stem } \\
\text { node no. }\end{array}$ & $\begin{array}{c}\text { Mature } \\
\text { plant height }\end{array}$ & $\begin{array}{c}\text { Mature } \\
\text { plant density }\end{array}$ & $\begin{array}{c}\text { R8 plant } \\
\text { maturity date }\end{array}$ & $\begin{array}{l}\text { Seed } \\
\text { yield }\end{array}$ & $\begin{array}{c}100 \text {-seed } \\
\text { weight }\end{array}$ & $\begin{array}{l}\text { Seed protein } \\
\text { content }\end{array}$ & $\begin{array}{l}\text { Seed oil } \\
\text { content }\end{array}$ \\
\hline Year $(Y)$ & 1 & 3 & 0.61 & 0.17 & 0.71 & 0.07 & 0.41 & 0.66 & 0.77 & 0.92 \\
\hline Planting date (PD) & 3 & 3 & 0.03 & 0.01 & 0.99 & 0.02 & 0.15 & 0.73 & 0.83 & 0.46 \\
\hline Linear & 1 & 3 & 0.007 & 0.004 & 0.93 & 0.006 & 0.04 & 0.98 & 0.43 & 0.16 \\
\hline Quadratic & 1 & 3 & 0.20 & 0.03 & 0.78 & 0.98 & 0.86 & 0.34 & 0.89 & 0.88 \\
\hline Cubic & 1 & 3 & 0.66 & 0.70 & 0.96 & 0.80 & 0.79 & 0.84 & 0.86 & 0.93 \\
\hline$Y \times P D$ & 3 & 15 & 0.004 & 0.051 & 0.01 & $<0.0001$ & $<0.0001$ & $<0.0001$ & $<0.0001$ & $<0.0001$ \\
\hline Linear & 1 & 444 & 0.004 & 0.72 & 0.001 & $<0.0001$ & $<0.0001$ & $<0.0001$ & $<0.0001$ & 0.0001 \\
\hline 2003 & 1 & $444^{\dagger}$ & $<0.0001$ & $<0.0001$ & 0.04 & $<0.0001$ & $<0.0001$ & 0.0005 & 0.0001 & 0.053 \\
\hline 2004 & 1 & $444^{\dagger}$ & $<0.0001$ & $<0.0001$ & 0.02 & $<0.0001$ & $<0.0001$ & 0.0003 & $<0.0001$ & $<0.0001$ \\
\hline Quadratic & 1 & 444 & 0.01 & 0.01 & 0.87 & 0.36 & 0.47 & 0.04 & 0.046 & $<0.0001$ \\
\hline 2003 & 1 & $444^{+}$ & 0.19 & 0.001 & 0.53 & 0.56 & 0.17 & 0.15 & 0.47 & 0.0008 \\
\hline 2004 & 1 & $444^{+}$ & $<0.0001$ & $<0.0001$ & 0.69 & 0.47 & 0.64 & $<0.0001$ & 0.02 & 0.01 \\
\hline Cubic & 1 & 444 & 0.26 & 0.76 & 0.22 & 0.50 & 0.01 & 0.08 & 0.22 & 0.93 \\
\hline 2003 & 1 & $444^{\dagger}$ & 0.90 & 0.70 & 0.46 & 0.15 & 0.86 & 0.51 & 0.95 & 0.86 \\
\hline 2004 & 1 & $444^{+}$ & 0.12 & 0.45 & 0.36 & 0.62 & 0.003 & 0.07 & 0.06 & 0.77 \\
\hline Cultivar (C) & 13 & 21 & $<0.0001$ & $<0.0001$ & 0.02 & 0.03 & 0.003 & 0.0006 & 0.0009 & $<0.0001$ \\
\hline $\mathrm{Y} \times \mathrm{C}$ & 13 & 39 & 0.04 & 0.11 & 0.0006 & 0.04 & 0.051 & 0.62 & 0.21 & 0.09 \\
\hline$P D \times C$ & 39 & 39 & 0.007 & 0.11 & 0.82 & 0.77 & 0.02 & 0.62 & 0.90 & 0.53 \\
\hline $\mathrm{Y} \times \mathrm{PD} \times \mathrm{C}$ & 39 & 312 & 0.61 & 0.59 & 0.58 & $<0.0001$ & 0.52 & 0.02 & $<0.0001$ & 0.01 \\
\hline
\end{tabular}

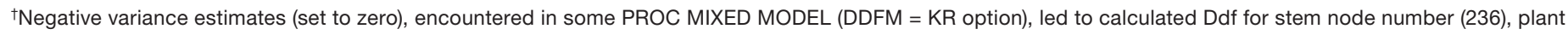
height (69), and plant density (287) that are not shown in the table but were lower than the indicated Ddf value (444) that was calculated for the other traits. 


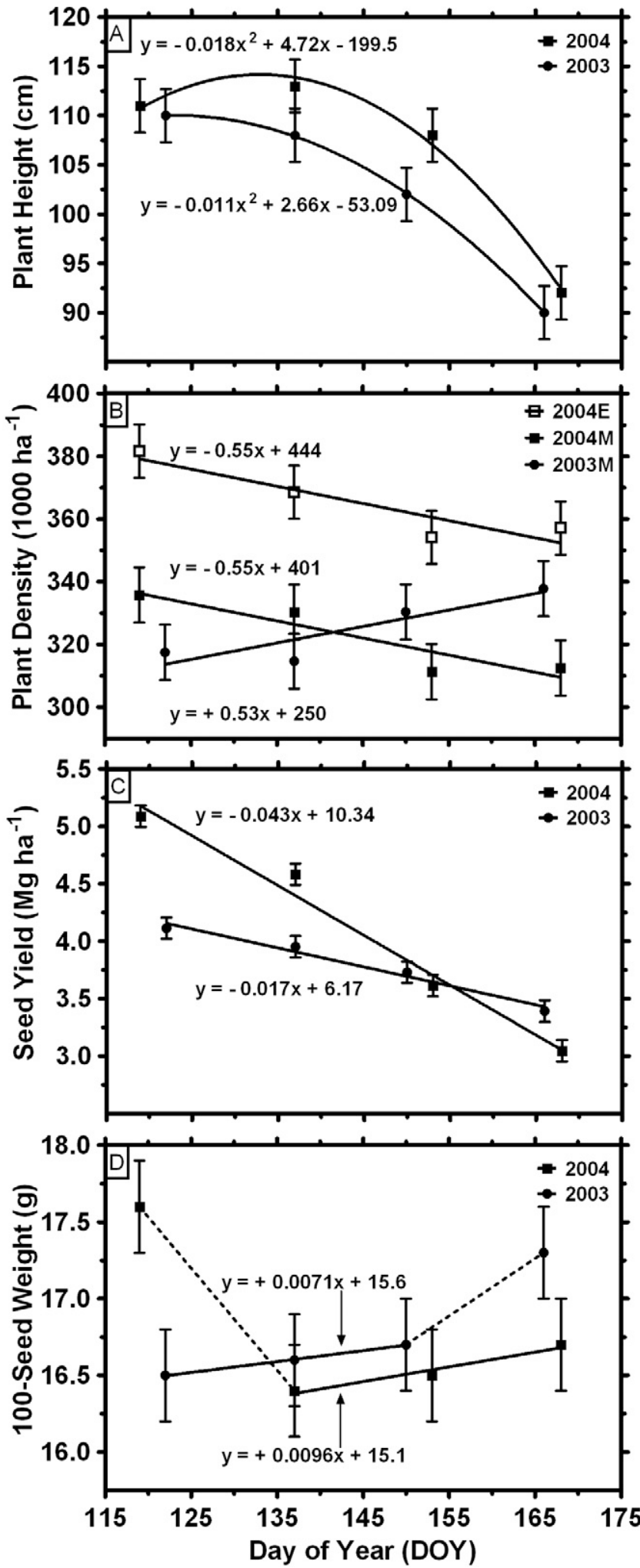

Figure 5. Means for planting dates within each year $(n=56$ for each symbol) for (A) plant height; (B) plant density at emergence (E) (2004 only) and at maturity (M); (C) seed yield; (D) final 100-seed weight. The best-fitting regression (quadratic or linear) was computed for the four data points of each year, except for 100-seed weight, for which linearity was evident for only three of the four data points each year (see text for further details).

\section{Yield and Its 100-Seed Weight Component}

Yield was significantly affected by a year $\times$ planting date interaction (Table 3 ), which arose because the linear yield decline per day of planting delay was small $\left(17 \mathrm{~kg} \mathrm{ha}^{-1} \mathrm{~d}^{-1}\right)$ in 2003, but large $\left(43 \mathrm{~kg} \mathrm{ha}^{-1} \mathrm{~d}^{-1}\right)$ in 2004 (Fig. 5C). These observed linear declines were congruent with the linear yield decline of $22.2 \mathrm{~kg} \mathrm{ha}^{-1} \mathrm{~d}^{-1}$ from 1 May to 10 June observed by Beuerlein (1988). The yield decline in 2004 was slightly sigmoidal, generating a significant (cubic) year $\times$ planting date interaction. Comparatively, the total yield reduction arising from a $45-\mathrm{d}$ delay of planting from May 1 to June 15 was $745 \mathrm{~kg} \mathrm{ha}^{-1}$ in 2003 (colder spring but warmer summer), but a more substantive $1950 \mathrm{~kg} \mathrm{ha}^{-1}$ in 2004 (warmer spring but cooler summer). Cultivar yields ranged from a low of $3.6 \mathrm{Mg} \mathrm{ha}^{-1}$ for Nebraska line U98-311442 to a high of $4.1 \mathrm{Mg} \mathrm{ha}^{-1}$ for Pioneer $93 \mathrm{~B} 36$. The yield of each cultivar (except that of U98-307162) rose linearly as the sowing date was advanced, but because cultivars differed in the steepness of that linear response, there was a significant (linear only) planting date $\times$ cultivar interaction.

The response of 100-seed weight to sowing date was linear, but only for three of the four sowing dates within each year, leading to a significant year $\times$ planting date interaction (Table 3). There was no planting date $\times$ cultivar interaction. As shown in Fig. 5D, 100-seed weight increased $0.007 \mathrm{~g} \mathrm{~d}^{-1}$ as planting was delayed from early May to late May in 2003, but the (last) mid-June planting generated a somewhat larger increase than expected based on extrapolation of that year's three-point regression. In 2004,100 -seed weight increased $0.009 \mathrm{~g} \mathrm{~d}^{-1}$, but only over the last three planting dates. Surprisingly, the 100-seed weight generated in the late April 2004 planting date did not decrease as might be expected from extrapolation of the 2004 three-point regression, and instead increased by about $1.4 \mathrm{~g}$. The year $\times$ planting date response patterns for individual cultivars differed appreciably enough from the mean response pattern shown in Fig. 5D to cause a significant $(P=0.02)$ three-way interaction, but differences were not substantive enough to be of much agronomic significance. Cultivar NE3001 produced (as expected)

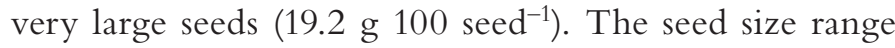
in the other cultivars was more modest, from the largest, Pioneer 93B36 (17.6 g 100 seed $^{-1}$ ), to the smallest, Kaup $335\left(15.7 \mathrm{~g} 100 \mathrm{seed}^{-1}\right)$.

\section{Seed Constituents}

Seed protein and seed oil contents were inconsistently influenced by year and planting date (Table 3). As planting was delayed, seed protein was linearly reduced in 2003 , but linearly enhanced in 2004. Seed oil was reduced by delays in planting date, although the 2003 first planting date did not follow this pattern. In both cases, this gave rise to a year $\times$ planting date interaction. These inconclusive data, 
plus the significant three-way interaction, precluded any broad generalizations about the impact of planting date on these seed constituents. Pedersen and Lauer (2003) reported that planting date did not have an effect on seed protein content in their study, though Helms et al. (1990) observed that seed oil content decreased when planting was delayed.

\section{DISCUSSION}

The triphasic linear profile of soybean stem node accrual observed in each planting date (Fig. 1) was more consistent with a model of three separate lines rather than a sigmoid curve. Logistic functions are usually preferred for modeling crop growth because of the parsimony principle, that is, only three or four parameters need to be estimated (Yin et al., 2003). A three-segment linear regression model has six parameters (though the y-intercept is fixed). However, logistic models also implicitly assume a symmetric (or asymmetric) inflection point demarking when a continuously changing growth rate moves from proximal acceleration to distal deceleration-a presumption that is actually less parsimonious, from a biological point of view, than is linearity in each distinct growth phase (van der Weele et al., 2003). In our data, the three-segment linear regression model was superior to the logistic model based on F-tests of goodness-of-fit vs. model complexity $(P<0.001$ or less in seven data sets, and $P<0.01$ in the eighth one).

The model fits of three-segment linear regression are graphically depicted in Fig. 2 and tabulated in Table 2 , along with the R-stage DAP values derived from the R-stage standard curves discussed in Materials and Methods. In seven of the eight sowing dates, the DAP differential between V1 and R1 was a remarkably near-constant 28 to $31 \mathrm{~d}$, reflecting the dependency of the R 1 date on the date of V1. Wilkerson et al. (1989) evaluated MG 3 cultivars grown in chambers at constant $26^{\circ} \mathrm{C}$ temperature in a strongly inductive photoperiod, and observed that floral induction commenced at V0 and was completed at V1. They reported that $\mathrm{R} 1$ routinely occurred about $20 \mathrm{~d}$ after V1. The 8- to 11-d longer V1 to R1 periods observed in our field study likely reflected the less strongly inductive (natural) photoperiods and cooler temperatures.

The regression breakpoints $\mathrm{X} 0$ and $\mathrm{X} 1$, which define the start and end of the central B2 slope (Fig. 2), corresponded closely with $\mathrm{V} 1$ and R5. The DAP estimate for V1 fell within the $95 \%$ confidence interval of the X0 DAP values in six of the eight data sets (Table 2). Though the R5 DAP estimate fell within the X1 DAP confidence interval in only two data sets, the R5 DAP values in four other data sets were just a day or two short of inclusion. Despite these exceptions, R 5 was obviously closer in timing to X1 than any other R-stage integer (Fig. 2). Newly developing seeds at R 5 are strong sinks, and the diversion of photosynthate from the primordial sinks at the stem apex is often cited as the physiological reason for the cessation of node production (Hesketh et al., 1973). Sinclair (1984a) noted that cessation of nodal leaf emergence corresponded with stage R5, as did Egli et al. (1985) and Pedersen and Lauer (2004a). We conclude that V1 and R5 likely represent biological events of significance relative to the start and end of the predominant central (i.e., B2) phase of soybean linear node accrual.

The transition in node accrual rate before and after X0 (and X1) is explicitly abrupt in a trisegment linear regression model, but maximally smooth in a logistic model. Not willing to settle for either extreme, van der Weele et al. (2003) created a bilinear regression model with parameters for characterizing breakpoint shape. Peters and Baskin (2006) observed that this six-parameter bilinear model was superior to the four-parameter Richards function (the most flexible of the logistic equations). Successful fitting of the bilinear model presumes a zero B3 slope and requires exceptionally frequent observational data in the $\mathrm{X} 0$ breakpoint region, which our data sets lacked (Fig. 1). We regret not taking at least daily $\mathrm{V}$-stage observations during the $\mathrm{X} 0$ and X1 breakpoint intervals. We also should have continued the twice-weekly 10-plant V-stage data collection until R7 (Fig. 2), since that data would have allowed a better assessment of whether our B3 slope estimates after R6 were intrinsically zero (Table 2). For those interested in using a bilinear model to confirm or refute our node accrual observations in other latitudes, these shortcomings in our sampling methods should be avoided.

The B2 slope parameter estimate was 0.27 node $\mathrm{d}^{-1}$ for the first three sowing dates, but a significantly lower 0.24 node $\mathrm{d}^{-1}$ for last sowing date (Table 2 ). These slopes translated into respective phyllochrons of 3.7 and $4.1 \mathrm{~d}_{\text {node }}{ }^{-1}$ for a V1 to R 5 interval of about $65 \mathrm{~d}$ in the first sowing date, and about $60 \mathrm{~d}$ in the last sowing date (Fig. 2). In DOY terms (Fig. 1), the 60-d V1 to R5 period of the midJune sowing date was clearly coincident with warmer seasonal temperatures, so the lower, rather than higher (B2) node accrual estimate was puzzling. In any event, the two phyllochron estimates ( 3.7 to $4.1 \mathrm{~d}$ ) and their constancy from V1 to R1 were not congruent with the often-cited Fehr and Caviness (1977) statement that the number of days between successive $\mathrm{V}$-stages can be quite variable, depending on temperature, and that a new node can be expected about every $3 \mathrm{~d}$ after V5. It is possible, of course, that our 3.7-d phyllochron estimate is not extrapolatable beyond our latitude of MG 3 soybean adaptation. Still, we feel at ease in conveying to MG 3 soybean producers that a 3.7-d phyllochron creates nearly two new soybean nodes per week during the 2-mo V1 to R1 period.

Most biological and metabolic processes (except biological clocks) display some sort of $Q_{10}>1$ response to rising temperatures. However, despite a seasonal temperature rise from about $10-15^{\circ} \mathrm{C}$ in the spring to 
about $20-30^{\circ} \mathrm{C}$ in the summer (Table 1, Fig. 1, top), no upwardly inflective curvature was statistically discernible in the B2 slope intervals. Sinclair (1984b) reported a constant $4-\mathrm{d}$ phyllochron in Florida when air temperatures averaged $22^{\circ} \mathrm{C}$. A $4-\mathrm{d}$ phyllochron was evident in the Wisconsin data of Pedersen and Lauer (2004a), though not mentioned. Hesketh et al. (1973) is frequently cited in crop modeling papers because these authors documented substantial temperature sensitivity of the phyllochron when MG 3 cultivar Wayne was grown in summer greenhouses set to season-long day/night (mean) temperatures of $17 / 11^{\circ} \mathrm{C}\left(13^{\circ} \mathrm{C}\right), 20 / 17^{\circ} \mathrm{C}\left(18^{\circ} \mathrm{C}\right), 23 / 20^{\circ} \mathrm{C}$ $\left(21^{\circ} \mathrm{C}\right), 26 / 23^{\circ} \mathrm{C} \quad\left(24^{\circ} \mathrm{C}\right), 32 / 23^{\circ} \mathrm{C}\left(26^{\circ} \mathrm{C}\right), 29 / 26^{\circ} \mathrm{C}$ $\left(27^{\circ} \mathrm{C}\right)$, and $32 / 29^{\circ} \mathrm{C}\left(30^{\circ} \mathrm{C}\right)$. These temperature regimes generated respective phyllochrons of 8.0, 4.9, 3.8, 2.9, 2.6, 2.4, and 2.3 d. In Fig. 2, we have depicted the daily (24-h) temperature means in 2003 and 2004 for the periods between the vertical V1, R1, and R 5 lines in each of the planting date models. In the early May 2003 sowing date, for example, the daily temperature average was $21.8^{\circ} \mathrm{C}$ during the $\mathrm{V} 1$ to $\mathrm{R} 1$ phase of the $\mathrm{B} 2$ slope, but was $25.8^{\circ} \mathrm{C}$ during the $\mathrm{R} 1$ to $\mathrm{R} 5$ phase of that same slope- $-4^{\circ} \mathrm{C}$ differential. If the greenhouse data of Hesketh et al. (1973) were transferable to the field, then a 3.8-d phyllochron would have been expected (and was observed) in the proximal half of B2, but a faster 2.9-d (or less) phyllochron would have been expected (but was not observed) in the distal half. Moreover, a $25^{\circ} \mathrm{C}$ mean temperature, which occurred in the last half of several B2 periods (Fig. 2), was expected to generate a 2.8-d phyllochron (but did not). Our data indicated that field-based node accrual during V1 to R1 was not very temperature sensitive, relative to that seen in the greenhouse by Hesketh et al. (1973). We do note that they used photoperiod regimes (i.e., day/night of $17 / 7 \mathrm{~h}$ from sowing until V4, 13/11 h until R2 or R3, and then 16/8 h until R8) that do not naturally occur in the field in our latitudes of $\mathrm{MG}$ 3 soybean production.

Delaying the sowing date by about $45 \mathrm{~d}$ from early May to mid-June increased the B1 slope from 0.0024 to 0.09 nodes $\mathrm{d}^{-1}$ and shortened its duration to $\mathrm{X} 0$ from 32 to $10 \mathrm{~d}$ (Table 2). Both effects were likely ascribable to the warmer coincident temperatures during the B1 period (Fig. 2). The pre-V1 vegetative development period was thus sensitive to temperature, at least to a degree that the subsequent V1 to R 5 node accrual period was not. However, the sensitivity of the $\mathrm{B} 1$ period might have been better characterized if, instead of relying on air temperature data, we had used sensors to monitor temperature of the soil surrounding the germinating seeds and temperature of the soil surface near emerging seedlings. We advise other researchers to do so when examining planting date effects on the $\mathrm{B} 1$ rate and its duration in pre-V1 development.
The pre-V1 period involves morphological changes that were documented by Miksche (1961), who noted that the dormant soybean seed has two partially developed unifoliolate leaves on a plumule whose apical meristem also has a barely discernible first trifoliolate leaf primordium. Thus, the first three V-stage nodes-cotyledonary (0), unifoliolar (1), and immature trifoliolar (2) - are already present. The second trifoliolar primordium (3) is observable on the epicotyl apex about $84 \mathrm{~h}$ after germination (i.e., $84 / 24=3.5-\mathrm{d}$ plastochron), with the third trifoliolar primordium (4) visible just $48 \mathrm{~h}$ thereafter (i.e., a 2-d plastochron). The sixth (7) and seventh (8) trifoliolar primordia are observable on the 11th and 13th days after germination (i.e., about stage V0), which led Miksche (1961) to conclude that soybean had a 2-d plastochron in greenhouse conditions. Johnson et al. (1960) observed that just $35 \mathrm{~d}$ after a mid-May field planting (about V5), the stem apex had already produced all of the leaf primordia that were eventually to form (i.e., 19 total nodes, most still microscopic), which Lersten and Carlson (2004) noted was also evidence for a $2-\mathrm{d}$ plastochron. It is difficult to envision how a plastochron of a constant $2 \mathrm{~d}$ between successively initiated leaf primordia can be congruent with a phyllochron of a constant 3.7 to $4.1 \mathrm{~d}$ between successively emergent leaves. This incongruity was also noted in wheat (Triticum aestivum L.) by Hunt et al. (2003) and is of great interest to researchers studying the molecular mechanics of stem morphogenesis (Reddy et al., 2004).

Stem internode lengths exhibited (from node 3 upward) a parabolic-like pattern that could be described as a Lorentzian curve (Fig. 4). Planting date had little impact on the length of the longest internode, as shown by a global model fit of $8.6 \mathrm{~cm}$ for Lorentzian peak amplitude in all eight data sets. The 45-d delay from the first to the last sowing date lowered the position of this peak from main stem node 12 to 10 , and simultaneously narrowed the peak width by about two nodes. Though plants in the last planting date still had longer internodes at stem nodes 3 to 10 than did plants in the first planting date, this advantage was offset by their comparably much shorter internodes at nodes 12 and higher. It is worth noting that there was very little difference between the early and mid-May sowing dates relative to stem internode length (Fig. 3 and 4).

A biologically plausible explanation for the Lorentzian curve pattern is that "internode elongation" is functionally analogous to "seed-filling." If so, then as new trifoliolate leaves emerge at 3.7-d intervals from early to late spring, ever-greater amounts of photosynthate become available for the "filling" of each successive internode, thus leading to successively ever-longer internodes before the peak, but resulting in ever-shorter internodes thereafter due to a diversion of ever-greater amounts of photosynthate from "internode-filling" to support reproductive organ development. Of obvious interest, then, is the R-stage coinci- 
dent with this peak. The sowing-date-specific stem node values of the Lorentzian peak centers shown in Fig. 4 were added to the Fig. 2 graphs as horizontal lines. Based on the intersection of that horizontal line with the R-stage vertical lines, it is apparent that the R3 (begin pod) stage corresponds with the peak in internode length. This supports the notion that photosynthate demand by newly developing pods at R3 reduces the amount of photosynthate available for "internode filling." However, it does not do so with respect to $\mathrm{B} 2$ node accrual, since the latter continues unabated until R5 (Fig. 2), when most if not all photosynthate is then presumably diverted to seed-filling.

The linear decline in seed yield observed as planting was delayed in this study highlights the importance of early sowing for maximizing the yield potential of irrigated soybean production in the western Corn Belt. Advancing the sowing date from mid-June to early May or late April lengthens the days to V1 after sowing-due to the temperature sensitivity of germination and emergence-but it also advances V1 on a calendar date basis (Fig. 1), thereby leading to an earlier seasonal start of node accrual and floral induction. Given our finding that the linearity in post-V1 node accrual rate is not significantly depressed by cooler temperatures (of a typical seasonal range), an earlier start of node production can be expected to optimize the final number of main stem nodes. Because R1 occurs about 28 to $31 \mathrm{~d}$ after $\mathrm{V} 1$, irrespective of planting date (Table 2), an earlier V1 also results in a seasonally earlier R1. Cooper (2003) theorized that soybean yield potential in the Corn Belt could be enhanced if breeders could genetically advance R1 relative to vegetative development. Our data indicate that earlier planting is a managerial means of achieving Cooper's earlier flowering objective, given the DOY advance in R1 date that results. Yield potential is likely enhanced when more nodes are available to serve as sites for reproductive development, and when the R1 to R7 interval is lengthened (Fig. 2, Table 2).

We recognize that, in many published planting date studies, yields often reached a maximum in mid-May, with early May or late April sowings leading to no better yields. Fungicide-treated seed was not used in those studies, whereas it was used in all of our planting dates, and this factor might have accounted for the difference in the yield response to very early planting. Alternatively, in planting date studies conducted in rainfed conditions, sowing dateinduced shifts in seed-filling periods can lead to differential seed yield impacts arising from the timing of local August rainfall events and/or soil water deficits. Our use of irrigation in this study did offer us the opportunity to experimentally detail the nature of vegetative and reproductive development over a 7-wk span in sowing dates, without the effects of erratically timed summer water stress confounding the per se effects of planting date.

\section{Acknowledgments}

The senior author A. Bastidas thanks Monsanto Company for providing partial funding support of her graduate research assistantship. The authors thank the departmental reviewers Wallace Wilhelm and Mark Bernards, the Crop Science reviewers, and the associate editor for their constructively critical reviews of this manuscript. The corresponding author, J.E. Specht, especially thanks technical editor Donald Bullock for his assistance in helping conduct a PROC MIXED reanalysis of the experimental data with all effects considered random except planting date. This analysis not only improved the estimation of the main effects and their interactions, but also enhanced the scope of the conclusions inferred from the results.

\section{References}

Allen, R.G., L.S. Pereira, D. Raes, and M. Smith. 1998. PenmanMonteith equation. In Crop evapotranspiration: Guidelines for computing crop water requirements. FAO Irrigation and Drainage Paper No. 56. Available at www.fao.org/docrep/X0490E/ x0490e00.htm\#Contents (verified 11 Dec. 2007). FAO, Rome.

Anderson, L.R., and B.L. Vasilas. 1985. Effects of planting date on two soybean cultivars: Seasonal dry matter accumulation and seed yield. Crop Sci. 25:999-1004.

Beaver, J.S., and R.R. Johnson. 1981. Response of determinate and indeterminate soybeans to varying cultural practices in the northern USA. Agron. J. 73:833-838.

Beuerlein, J.E. 1988. Yield of indeterminate and determinate semidwarf soybean for several planting dates, row spacings, and seeding rates. J. Prod. Agric. 1:300-303.

Boote, K.J., J.W. Jones, W.D. Batchelor, E.D. Nafziger, and O. Myers. 2003. Genetic coefficients in the CROPGRO-Soybean model: Links to field performance and genomics. Agron. J. 95:32-51.

Cooper, R.L. 2003. A delayed flowering barrier to higher soybean yields. Field Crops Res. 82:27-35.

Egli, D.B., R.D. Guffy, and J.E. Legget. 1985. Partitioning of assimilate between vegetative and reproduction growth in soybean. Agron. J. 77:917-922.

Elmore, R.W. 1990. Soybean cultivar response to tillage systems and planting date. Agron. J. 82:69-73.

Erickson, R.O., and F.J. Michelini. 1957. The plastochron index. Am. J. Bot. 44:297-305.

Fehr, W.R., and C.E. Caviness. 1977. Stages of soybean development. Special Report 80. Iowa Agric. Home Econ. Exp. Stn., Iowa State Univ., Ames.

Fehr, W.R., C.E. Caviness, D.T. Burmood, and J.S. Pennington. 1971. Stage of development descriptions for soybean, Glycine $\max ($ L.) Merrill. Crop Sci. 11:929-931.

Helms, T.C., C.R. Hurburgh, Jr., R.L. Lussenden, and D.A. Whited. 1990. Economic analysis of increased protein and decreased yield due to delayed planting of soybean. J. Prod. Agric. 3:367-371.

Hesketh, J.D., D.L. Myhre, and C.R. Willey. 1973. Temperature control of time intervals between vegetative and reproductive events in soybeans. Crop Sci. 13:250-254.

Hoeft, R.G., E.D. Nafziger, R.R. Johnson, and S.R. Aldrich. 2000. Modern corn and soybean production. MCSP Publications, Champaign, IL.

Hofstra, G., J.D. Hesketh, and D.L. Myhre. 1977. A plastochron model for soybean leaf and stem growth. Can. J. Plant Sci. $57: 167-175$. 
Hunt, L.A., M.P. Reynolds, K.D. Sayre, S. Rajaram, J.W. White, and W. Yan. 2003. Crop modeling and the identification of stable coefficients that may reflect significant groups of genes. Agron. J. 95:20-31.

Johnson, H.W., H.A. Borthwick, and R.C. Leffel. 1960. Effects of photoperiod and time of planting on rates of development of the soybean in various stages of the life cycle. Bot. Gaz. 122:77-95.

Lersten, N.R., and J.B. Carlson. 2004. Vegetative morphology. p. 15-57. In H.R. Boerma and J.E. Specht (ed.) Soybeans: Improvement, production, and uses. 3rd ed. ASA, Madison, WI.

Littell, R.C., G.A. Milliken, W.W. Stroup, and W.W. Wolfinger. 1996. SAS system for mixed models. SAS Inst., Cary, NC.

McMaster, G.S., and L.A. Hunt. 2003. Re-examining current questions of wheat leaf appearance and temperature. $\mathrm{p}$. 18-22. In J.W. White (ed.) Modeling temperature response in wheat and maize: Proceedings of a workshop, CIMMYT, El Batan, Mexico. 23-25 Apr. 2001. NRG-GIS Series 03-01. CIMMYT, Mexico, D.G.

Miksche, J.P. 1961. Developmental vegetative morphology of Glycine max. Agron. J. 53:121-128.

Monks, C.D., D. Delaney, J. Everest, and D. Weaver. 1988. Soybean growth and development in Alabama. ANR-1089. Alabama A\&M and Auburn Universities, Alabama Coop. Ext. System.

Motulski, H.J., and A. Christopoulos. 2003. Fitting models to biological data using linear and nonlinear regression. A practical guide to curve fitting. Available at www.graphpad.com/ manuals/prism4/RegressionBook.pdf (verified 11 Dec. 2007). GraphPad Software, Inc., San Diego, CA.

Naeve, S.L., B.D. Potter, S.R. Quiring, T.A. O’Neill, and J.E. Kurle. 2004. Influence of soybean plant population and row spacing on development and yield across planting dates in Minnesota. Available at www.soybeans.umn.edu/pdfs/2004asaposter_1_spacingplanting_screen.pdf (verified 11 Dec. 2007). Univ. of Minnesota, Minneapolis.

Oplinger, E.S., and B.D. Philbrook. 1992. Soybean planting date, row width, and seeding rate response in three tillage systems. J. Prod. Agric. 5:94-99.

Pachepsky, Y.A., V.R. Reddy, L.B. Pachepsky, F.D. Whisler, and B. Acock. 2002. Modeling soybean vegetative development in the Mississippi valley. Int. J. Biotronics 31:11-24.

Pecinovsky, K., and G.O. Benson. 2004. Twenty-six years of soybean planting date studies. Available at www.ag.iastate.edu/ farms/2001reports/ne/Twentysixyearsofsoybean.pdf (verified 11 Dec. 2007). Iowa State Univ. Northeast Res. and Demonstration Farms, Ames.

Pedersen, P. 2004. Soybean growth and development. PM1945. Available at extension.agron.iastate.edu/soybean/documents/ Soybean_growth_and_development.pdf (verified $11 \mathrm{Dec}$. 2007). Iowa State Univ. Ext., Ames.

Pedersen, P., and J.G. Lauer. 2003. Soybean agronomic response to management systems in the Upper Midwest. Agron. J. 95:1146-1151

Pedersen, P., and J.G. Lauer. 2004a. Soybean growth and development in various management systems and planting dates. Crop Sci. 44:508-515.

Pedersen, P., and J.G. Lauer. 2004b. Response of soybean yield components to management system and planting date. Agron. J. 96:1372-1381.
Pendleton, J.W., and E.E. Hartwig. 1973. Management. p. 211-237. In B.E. Caldwell (ed.) Soybeans: Improvement, production, and uses. ASA, Madison, WI.

Peters, W.S., and T.I. Baskin. 2006. Tailor-made composite functions as tools in model choice: The case of sigmoidal vs. bilinear growth profiles. Plant Methods 2:11-25.

Reddy, G.V., M.G. Heisler, D.W. Ehrhardt, and E.M. Meyerowitz. 2004. Real-time lineage analysis reveals oriented cell divisions associated with morphogenesis at the shoot apex of Arabidopsis thaliana. Development 131:4225-4237.

SAS Institute. 1999. SAS and IML language and procedures: Statistics, Version 8. SAS Inst., Cary, NC.

Schnebly, S.R., and W.R. Fehr. 1993. Effect of years and planting dates on fatty acid composition of soybean genotypes. Crop Sci. 33:716-719.

Setiyono, T.D., A. Weiss, J.E. Specht, A.M. Bastidas, K.G. Cassman, and A. Dobermann. 2007. Understanding and modeling the effect of temperature and daylength on soybean phenology under high-yield conditions. Field Crops Res. 100:257-271.

Sinclair, T.R. 1984a. Cessation of leaf emergence in indeterminate soybeans. Crop Sci. 24:483-486.

Sinclair, T.R. 1984b. Leaf area development in field-grown soybeans. Agron. J. 76:141-146.

Specht, J.E., A. Bastidas, F. Salvagiotti, T. Setiyono, A.J. Liska, A. Dobermann, D.T. Walters, and K.G. Cassman. 2006. Soybean yield potential and management practices required to achieve it. In L.S. Murphy (ed.) Proceedings of the 2006 Fluid Forum, Vol. 23 [CD-ROM]. Fluid Fertilizer Foundation, Manhattan, KS.

Specht, J.E., D.J. Hume, and S.V. Kumudini. 1999. Soybean yield potential: A genetic and physiological perspective. Crop Sci. 39:1560-1570.

van der Weele, C.M., H.S. Jiang, K.K. Palaniappan, V.B. Ivanov, K. Palaniappan, and T.I. Baskin. 2003. A new algorithm for computational image analysis of deformable motion at high spatial and temporal resolution applied to root growth. Roughly uniform elongation in the meristem and also, after an abrupt acceleration, in the elongation zone. Plant Physiol. 132:1138-1148.

Whigham, K., D. Farnwell, J. Lundvall, and D. Tranel. 2000. Soybean replant decisions. Available at www.extension.iastate. edu/Publications/PM1851.pdf (verified 11 Dec. 2007). Iowa State Univ. Ext., Ames.

Wilcox, J.R., and E.M. Frankenberger. 1987. Indeterminate and determinate soybean responses to planting date. Agron. J. 79:1074-1078.

Wilhelm, W.W., and G.S. McMaster. 1995. Importance of the phyllochron in studying development and growth in grasses. Crop Sci. 35:1-3.

Wilkerson, G.G., J.W. Jones, K.J. Boote, and G.S. Buol. 1989. Photoperiodically sensitive interval in time to flower of soybean. Crop Sci. 29:721-726.

Yin, X., J. Goudriaan, E.A. Lantinga, J. Vos, and H.J. Spiertz. 2003. A flexible sigmoid function of determinate growth. Ann. Bot. (Lond.) 91:361-371.

Zhang, L., J. Zhang, C.E. Watson, and S. Kyei-Boahen. 2004. Developing phenological prediction tables for soybean. Available at www.plantmanagementnetwork.org/cm/. Crop Manage. DOI 10.1094/CM-2004-1025-01-RS. 